\title{
Teaching Video NeuroImages: Choreoathetosis Due to Radiation-Induced Brachial Plexopathy
}

Teruhiko Sekiguchi, MD, PhD, Toshiro Kanazawa, MD, PhD, and Takuya Ohkubo, MD, PhD Neurology ${ }^{\circledR}$ 2021;96:e1489-e1490. doi:10.1212/WNL.0000000000010855

Figure Needle EMG and FDG-PET
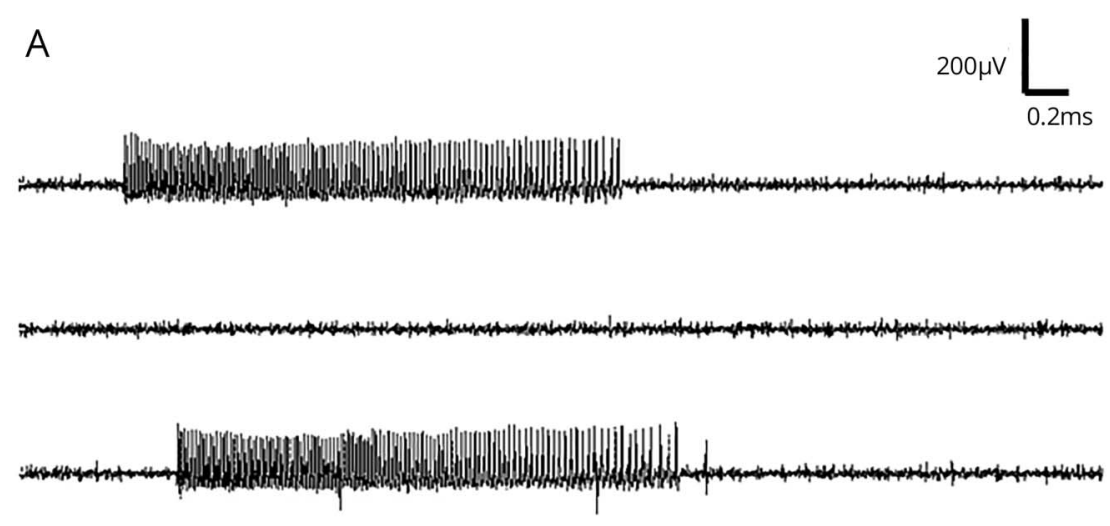

B

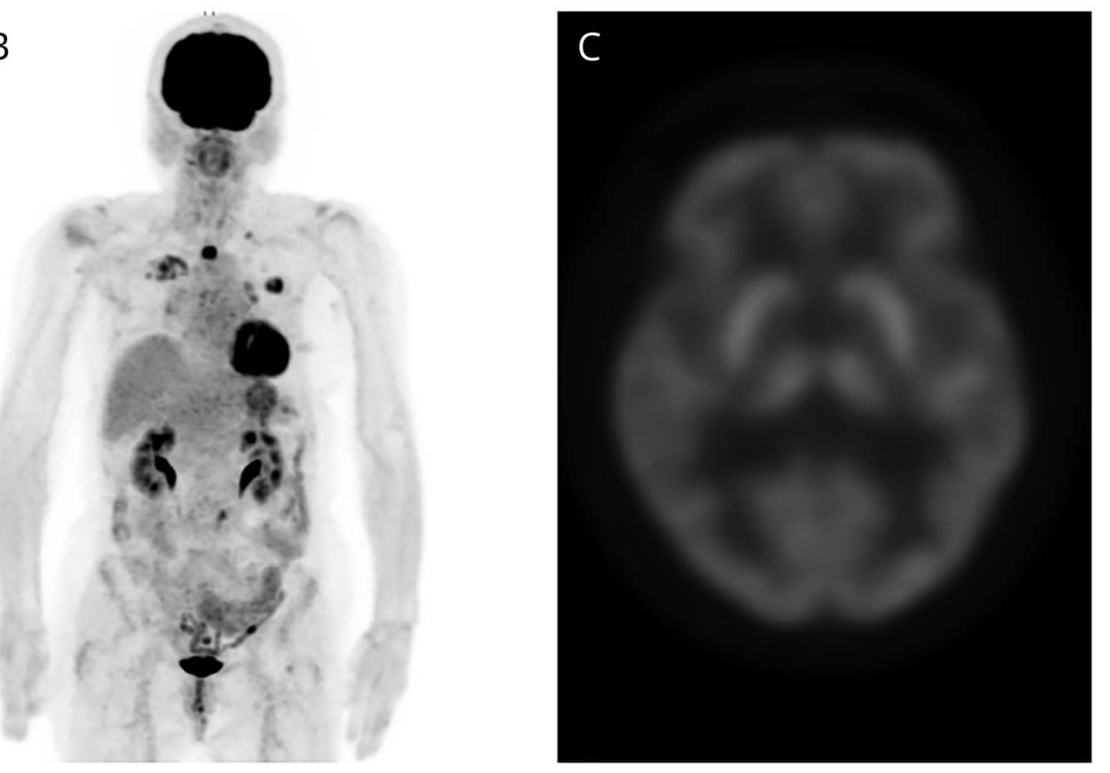

(A) Needle EMG recorded on the right flexor carpi radialis at rest showed repetitive myokymic discharges. (B) FDG-PET revealed increased uptake, suggestive of metastases, in the lungs and a vertebral body, distant from the right brachial plexus. (C) Uptakes of bilateral basal ganglia were symmetric.

A 69-year-old woman, whose right breast cancer had been treated by surgery and radiation at age 50, had right hand sensory loss and pain. The hand began to show choreoathetosis (video). Blood examination revealed that anti-Hu, anti-Yo, and anti-Ri antibodies were negative but antiSS-A antibody was positive without sicca syndrome. Neurogenic changes, including myokymic discharges, were present diffusely in the right arm on EMG (figure, A), suggesting radiation-

\section{Correspondence}

Dr. Sekiguchi

t-sekiguchi.nuro@tmd.ac.jp

\section{MORE ONLINE}

$\rightarrow$ Teaching slides

links.lww.com/WNL/

B228

- Video

From the Department of Neurology, Yokohama City Minato Red Cross Hospital, Japan.

Go to Neurology.org/N for full disclosures. Funding information and disclosures deemed relevant by the authors, if any, are provided at the end of the article. 
induced brachial plexopathy. Brain and cervical MRIs were normal. PET was normal within the right arm and the brain (figure, B and C). Two years later, both the choreoathetosis and myokymic discharges had ameliorated.

Radiation-induced plexopathy can cause choreoathetosis through pronounced myokymia of a broad range of muscles, which was called "painful arm and moving fingers." Ectopic impulses, generated from dorsal roots, are hypothesized to be transmitted to motoneurons via spinal interneurons. ${ }^{2}$ Such a pathomechanism may explain extremely asymmetric involuntary movements in our patient.

\section{Study Funding}

No targeted funding reported.

\section{Disclosure}

The authors report no disclosures relevant to the manuscript. Go to Neurology.org/ $\mathrm{N}$ for full disclosures.

\section{Appendix Authors}

\begin{tabular}{lll}
\hline Name & Location & Contribution \\
\hline $\begin{array}{l}\text { Teruhiko } \\
\text { Sekiguchi, } \\
\text { MD, PhD }\end{array}$ & $\begin{array}{l}\text { Department of Neurology, } \\
\text { Yokohama City Minato Red } \\
\text { Cross Hospital, Japan }\end{array}$ & $\begin{array}{l}\text { Major role in the } \\
\text { acquisition, analysis, and } \\
\text { interpretation of data; } \\
\text { drafted the manuscript for } \\
\text { intellectual content }\end{array}$ \\
\hline $\begin{array}{l}\text { Toshiro } \\
\text { Kanazawa, } \\
\text { MD, PhD }\end{array}$ & $\begin{array}{l}\text { Department of Neurology, } \\
\text { Cross Hospital, Japan }\end{array}$ & $\begin{array}{l}\text { Revised the manuscript for } \\
\text { intellectual content }\end{array}$ \\
\hline $\begin{array}{l}\text { Takuya } \\
\text { Ohkubo, } \\
\text { MD, PhD }\end{array}$ & $\begin{array}{l}\text { Department of Neurology, } \\
\text { Cokohama City Minato Red }\end{array}$ & $\begin{array}{l}\text { Revised the manuscript for } \\
\text { intellectual content }\end{array}$ \\
\hline
\end{tabular}

\section{References}

1. Verhagen WI, Horstink MW, Notermans SL. Painful arm and moving fingers J Neurol Neurosurg Psychiatry 1985;48:384-385.

2. Miyakawa T, Yoshimoto M, Takebayashi T, Yamashita T. Case reports: painful limbs/ moving extremities: report of two cases. Clin Orthop Relat Res 2010;468:3419-3425. 


\section{Neurology}

\section{Teaching Video NeuroImages: Choreoathetosis Due to Radiation-Induced Brachial Plexopathy}

Teruhiko Sekiguchi, Toshiro Kanazawa and Takuya Ohkubo

Neurology 2021;96;e1489-e1490 Published Online before print September 14, 2020

DOI 10.1212/WNL.0000000000010855

This information is current as of September 14, 2020

\section{Updated Information \&} Services

\section{References}

Subspecialty Collections

\section{Permissions \& Licensing}

Reprints including high resolution figures, can be found at: http://n.neurology.org/content/96/10/e1489.full

This article cites 2 articles, 1 of which you can access for free at: http://n.neurology.org/content/96/10/e1489.full\#ref-list-1

This article, along with others on similar topics, appears in the following collection(s):

All Clinical Neurology

http://n.neurology.org/cgi/collection/all_clinical_neurology Chorea

http://n.neurology.org/cgi/collection/chorea

EMG

http://n.neurology.org/cgi/collection/emg

Peripheral neuropathy

http://n.neurology.org/cgi/collection/peripheral_neuropathy

Radiation therapy-tumor

http://n.neurology.org/cgi/collection/radiation_therapytumor

Information about reproducing this article in parts (figures,tables) or in its entirety can be found online at:

http://www.neurology.org/about/about_the_journal\#permissions

Information about ordering reprints can be found online:

http://n.neurology.org/subscribers/advertise

Neurology ${ }^{\circledR}$ is the official journal of the American Academy of Neurology. Published continuously since 1951, it is now a weekly with 48 issues per year. Copyright (C 2020 American Academy of Neurology. All rights reserved. Print ISSN: 0028-3878. Online ISSN: 1526-632X.

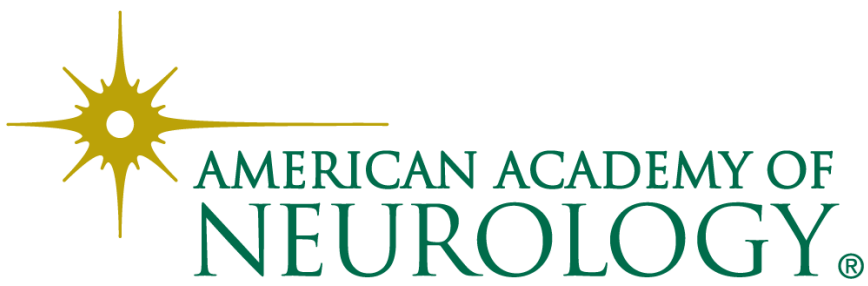

